\title{
Externalisation of a vein during venepuncture
}

\author{
Katherine Wade, ${ }^{1}$ Beatrice Robertson-Jones, ${ }^{1}$ Alastair Hutchison (i) ${ }^{2}$
}

${ }^{1}$ Dorset County Hospital NHS Foundation Trust, Dorchester, UK ${ }^{2}$ Trust Headquarters, Dorset County Hospital NHS Foundation Trust, Dorchester, UK

\section{Correspondence to}

Professor Alastair Hutchison; alastair.hutchison@dchft.nhs.uk

Accepted 27 January 2022

\section{DESCRIPTION}

A 65-year-old man presented with dyspnoea and chest pain. CT aortogram and ECHO identified a left atrial myxoma. He was noted to have CKD-2 (eGFR 67) and a coronary angiogram found moderate coronary artery disease (CAD). He had no history of diabetes, hypertension or family history of vascular disease. Body mass index was 24 , alcohol intake 4 units/week and total cholesterol 4.6, low-density lipoprotein 2.8 , triglycerides $0.9 \mathrm{mmol} / \mathrm{L}$. His only vascular risk factor was an 80-pack-year smoking history.

Venepuncture was attempted in the left antecubital fossa in a site previously used for cannulation with no evidence of inflammation or thrombosis. Initial venesection was successful, however blood flow then stopped. The needle was withdrawn, and surprisingly attached to the end of it was a thin, string-like structure (figure 1). Under tension, the structure had an elastic quality proximally with a firm, calcified distal end (figure 2) and its appearance was consistent with a vein rather than a nerve, artery or tendon. The location and size of the vein

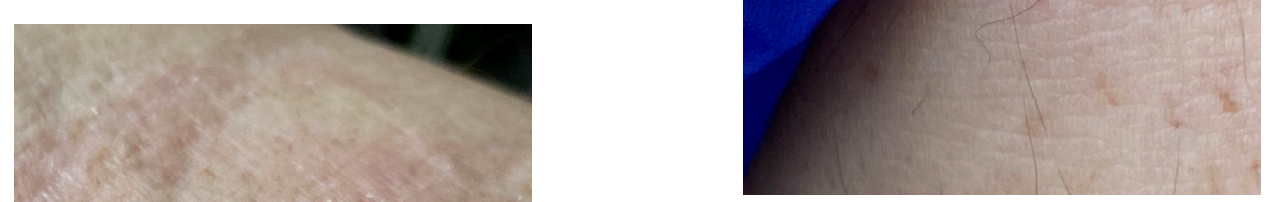

Figure 2 The vein shown under slight tension allowing the elastic 'healthy' segment that auto-retracted back into the arm to be visualised.

was consistent with the median cubital vein, and there were no clinical concerns regarding perfusion, sensation or movement.

The surgical team were consulted regarding management, and a rapid literature search was undertaken. Two management options were suggested: (1) surgical ligation of the proximal end of the exposed vein followed by excision or (2) allow to atrophy and auto-amputate.

Surgical ligation and excision was attempted, however, the relatively brief delay in obtaining surgical advice resulted in atrophy of the exposed distal portion. When tension was applied to the vein, the distal portion detached, leaving a proximal portion which auto-retracted under the skin before ligation was possible. This left a slight, non-tender swelling proximal to the puncture site, which likely represented a haematoma, and a sterile dressing was applied for 24 hours. The area was rested from venepuncture for several days but subsequent venepuncture was successful. Subsequently, a vascular surgeon advised in any future case, simpler
Figure 1 The vein shown shortly after the withdrawal of the needle. 


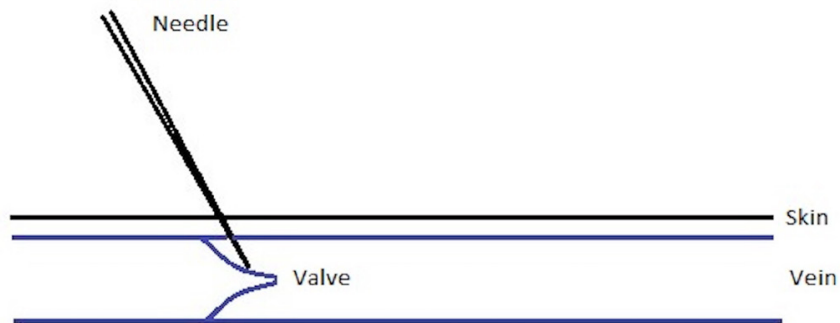

Figure 3 Diagram illustrating needle insertion into the calcified valve.

management would be to tension the vein until it ruptures and retracts under the skin, then apply firm pressure over the site.

Given the angiographic evidence of CAD, he may have also had venous calcification. Pedigo et $a l^{1}$ found $\sim 30 \%$ patients with CAD had calcium deposits within their saphenous veins. ${ }^{1}$ Venous calcification is thought to occur with increasing age, smoking history and chronic kidney disease. ${ }^{1}$ Vascular smooth muscle cells can de-differentiate to osteoblasts and mineralise deposited collagen in response to vessel injury.

As there are no literature reports of vein externalisation during venepuncture, it is difficult to be certain of the aetiology. Recent cannulation could have caused vascular injury and inflammation. However, we suggest that the tip of the needle became lodged in a calcified valve (represented by the calcified distal portion of the vein) (figure 3 ) allowing the attached valve and vessel to externalise when the needle was withdrawn (figure 4).

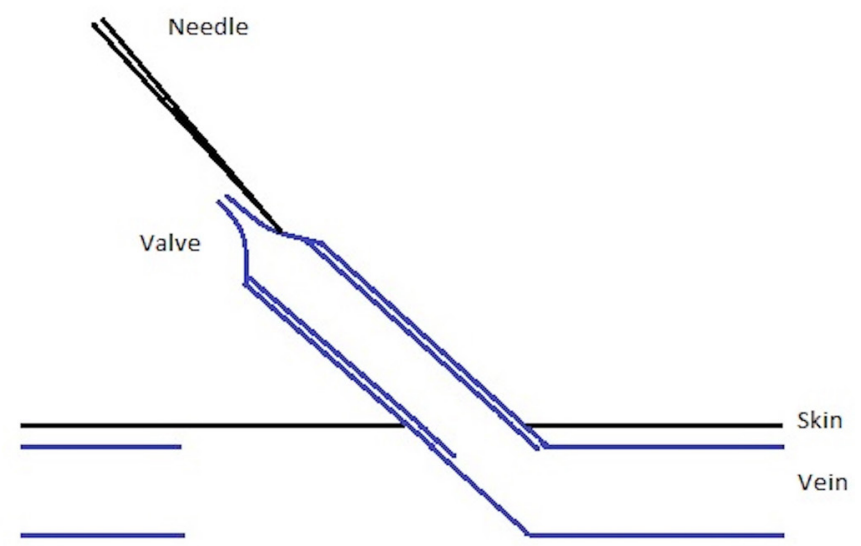

Figure 4 Diagram illustrating the externalisation of the vein.
Patient's perspective

I was curious to see what a vein really looked like. The whole experience was not painful at all. I was glad to be part of something which could help others learn how to manage a similar situation in the future.

\section{Learning points}

- This is a rare but potentially perplexing complication of venepuncture. Identifying features of an externalised vein include: initial successful venepuncture, subsequent bleeding from the elastic red-purple structure which soon clots, and anatomical correlation with the venous system.

- Management options of an externalised vein are (1) surgical ligation of the proximal end of the exposed vein followed by excision, which would be the preferred management particularly if the vein is still bleeding (2) atrophy and autoamputation or (3) tensioning the vein until it ruptures and retracts then apply firm pressure over the site.

\section{Twitter Alastair Hutchison@nephronuk}

Contributors The patient in the case report was under the care of BR-J and KW and both were involved in reviewing the patient following the procedure. BR-J was involved in discussing the management options with the surgical team and prepared to ligate the vein following advice. The case report was conceived by BR-J and jointly $B R-J$ and KW performed the literature review. KW and BR-J planned the case report and wrote the case report together. The case report was then designed and edited by $\mathrm{AH}, \mathrm{KW}$ and $\mathrm{BR}-\mathrm{J}$. KW, AH and BR-J were involved in editing multiple drafts of the case report. AH, KW and BR-J have approved the final version of the case report.

Funding The authors have not declared a specific grant for this research from any funding agency in the public, commercial or not-for-profit sectors.

Competing interests None declared.

Patient consent for publication Consent obtained directly from patient(s)

Provenance and peer review Not commissioned; externally peer reviewed.

Case reports provide a valuable learning resource for the scientific community and can indicate areas of interest for future research. They should not be used in isolation to guide treatment choices or public health policy.

ORCID iD

Alastair Hutchison http://orcid.org/0000-0003-3268-8324

\section{REFERENCE}

1 Pedigo SL, Guth CM, Hocking KM, et al. Calcification of human saphenous vein associated with endothelial dysfunction: a pilot Histopathophysiological and Demographical study. Front Surg 2017:4:1-6.

Copyright 2022 BMJ Publishing Group. All rights reserved. For permission to reuse any of this content visit https://www.bmj.com/company/products-services/rights-and-licensing/permissions/

BMJ Case Report Fellows may re-use this article for personal use and teaching without any further permission.

Become a Fellow of BMJ Case Reports today and you can:

- Submit as many cases as you like

- Enjoy fast sympathetic peer review and rapid publication of accepted articles

- Access all the published articles

- Re-use any of the published material for personal use and teaching without further permission

Customer Service

If you have any further queries about your subscription, please contact our customer services team on +44 (0) 2071111105 or via email at support@bmj.com.

Visit casereports.bmj.com for more articles like this and to become a Fellow 